\title{
Analysis of the Teaching Model of English Majors Based on the Idea of Work Process
}

\author{
Yu Shi ${ }^{1}$ \\ ${ }^{1}$ Wuhan Donghu University, Wuhan, Hubei, 430212
}

Keywords: English Major; Work Process; Teaching; Reform

\begin{abstract}
English teaching has developed on the basis of the increasingly close relationship between China and the world. Due to the development needs, English teaching has gradually developed toward the teaching direction of the "work process" concept. This paper starts from the concept of "work process" and discusses some issues and improvements in the construction of English teaching models.
\end{abstract}

\section{Introduction}

The English major is a specialized curriculum system that many colleges and universities have set up and have a long history of development. At the same time, English is also a very important curriculum content for higher education institutions. In other words, the English course is the core teaching content of the college English major's curriculum system. English majors in colleges and universities continue to infiltrate into other professional courses in the process of development. Nowadays, English majors in colleges and universities, professional coverage has gradually extended from the original English teaching system to other professional education. In the traditional college English teaching, the most important teaching focus is still on English listening, speaking, reading and writing. Although English is spoken as a language, its learning focus and learning content do not fall within this scope. However, from the perspective of professional learning, the aim of curriculum education for English majors in institutions of higher learning must not only be to enable students to master basic English knowledge, but also to have more educational content, such as the discipline literacy related to English. Through English professional learning to improve students' abilities in language learning, language communication, and language skills, the most important thing is that English teaching in universities and colleges is to systematically pass knowledge and skills related to English. Education to promote English majors' English subject quality and the promotion and development of English comprehensive ability. Specifically, English communication skills, foreign communication skills, English cultural communication skills, and bilingual business abilities are among the teaching goals of English teaching in colleges and universities.

Although the goals of English teaching in English majors of institutions of higher learning are well established, the innovation of teaching philosophy and teaching methods and strategies has also developed. However, in the practical operation of English majors in colleges and universities, some teachers are unfamiliar with the innovative teaching concepts and teaching methods, strategies, etc., or the teaching of English teachers often fails to attract students' interest in learning and improve students' abilities. The effect of learning positivity is that the direct result of this is that the teacher's teaching cannot achieve the goal of setting the expected teaching goal, and the students' English professional knowledge and skills learning cannot achieve good results. More importantly, because the mastery of professional knowledge and skills is not very solid, this makes it impossible for students to use English professional knowledge very well in the process of applying English professional knowledge and skills, resulting in ineffective teaching of English specialized knowledge and skills. 


\section{Analysis of English-oriented Major Education Model Based on Work Process}

Due to the current trend of curriculum reform, the final development trend of college English major teaching may be a combination of other professional disciplines, mutual contact and mutual promotion in the exchange, and gradually integrated into a training to adapt to social development. The high-quality comprehensive talents. The teaching goal of college English majors teaching will be changed from the prior emphasis on cultivating students' knowledge and skills in English to the professional English education that adapts the needs of modern talents to the development of modern society. The teaching of English under the guidance of the concept of "work process" refers to the teaching content of the English major, which not only includes the original English knowledge and skills, but also introduces the application of the knowledge and skills of the development of modern society to the development of the modern society. Sexual needs are the teaching objectives of English majors. They gradually focus on social needs, change their teaching concepts based on reality, and fulfill the society's expectation of training English professionals. The English teaching model based on the concept of "work process" has been proposed and gradually widely recognized and applied. It can also be seen that the English teaching model under the guidance of the "work process" concept has gradually been used by many English majors. With the approval of the education sector agencies. From another perspective, this also shows that the teaching philosophy of this English teaching model is consistent with the trend of the times and is in line with people's expectation for the teaching reform of English majors.

The specific English teaching concept under the guidance of the "work process" refers to the training goal that the English major teaching must highlight the work ability in the teaching goal, and infiltrates some vocational skills training and occupational competitiveness awareness in the English professional teaching content. Some of the things that students need to master in the course of their work, such as the promotion of professional standards. The promotion and development of this kind of teaching thought has changed the teaching of English majors in essence, and has made English teaching a new teaching idea from this new teaching concept, that is, no matter where it is taught in English. In one part, or in which link, or in which specific implementation process, English professional educators must deeply keep in mind this teaching premise for the development of professional abilities and will promote the development of students' professional abilities. Among the teachers' educational concepts, teachers are gradually infiltrating their teaching abilities in the process of English majors' teaching, which enables students to gain some training in professional competence in English major teaching.

There are some problems in the implementation of English teaching in the professional English teaching model based on the concept of "work process" has given the answer. That is to say, English teaching must be based on the needs of students' learning and development. From the research and investigation of students' development needs, we should design an English teaching program that meets the development needs of students, and then proceed on the premise of teaching programs that meet the students' development needs. Teaching operations. From the investigation of teachers, it can be found that students' mastery of knowledge is not only satisfied with knowledge learning and skills learning, but also requires the combination of theory and practice to carry out profound theoretical knowledge and theoretical reproduction, so that students can obtain practical The ability to improve.

\section{English Teaching Model Design under the Guidance of the "Work Process" Concept}

In fact, the English teaching model based on the concept of "work process" is not difficult to achieve, but it requires teachers to make some strategic improvements in teaching, so that English teaching can better fit students' professional abilities. Training objectives. For example, teachers can design some teaching situations to allow students to experience real knowledge application scenarios, such as targeted "Restaurant English" learning, "Music English" learning, and "Business English” learning. Targeted practical and practical knowledge learning and application practices 
have great help in obtaining the ability to upgrade from the English professional education.

In the implementation of specific English language teaching, teachers must clearly teach. The idea must be centered around the "work process", that is, the teacher's English major teaching must have a clear direction, that is, the "work process" as the orientation of English professional teaching. It is necessary to truly establish the basic teaching model of "English language teaching" with the "work process" as a guide. It is necessary to use new teaching methods or strategies that are innovative by teachers, so that teaching gradually moves towards the teacher's default. The direction of development, so that students can truly get the training and development of professional ability from the teacher's teaching. In order to achieve this teaching goal, teachers must make some changes. Here are some specific explanations of how the teachers are transformed.

Although there are difficulties in English teaching, many students have no interest in English teaching, no enthusiasm for participation, lack of enthusiasm for teaching, improper learning methods, and weak learning standards. However, teachers do not have any solutions. They can change the original form of collective teaching and use the methods of group cooperation in order to change the classroom teaching form. In the group cooperative learning, teachers are both organizers and participants, and students can propose to teachers. The teaching task is divided into learning and exploration, cooperation, discussion and exchange, which not only greatly enhances the student's learning efficiency, but also significantly improves the teacher's teaching effectiveness, and the students gradually form a kind of collaborative learning method in this group. New learning ideas will gradually become accustomed to and proficiently use this method of cooperative learning. They will gradually develop a sense of cooperation and cooperation in their own hearts, and their cooperation capabilities and team spirit will also be correspondingly developed.

Task-driven teaching method has been praised by many educators since it was universally promoted. Its teaching method focuses on student's research-based learning. Teachers are first arranged through a teaching task, and students have the motivation to solve problems. This motivation will motivate students to learn, explore, discover, and ultimately obtain solutions to problems. Under the guidance of such task-driven teaching methods, students will gain a sense of accomplishment and satisfaction with a specific task. Deep down there will have greater expectations for the next mission-driven teaching. Students' learning has a positive role in promoting. In addition, the task-driven method of teaching has the added advantage of allowing teachers to select the specific task of the task-driven teaching method. At this time, the dominance of the entire teaching is in the hands of the teacher. It is through the design of a theory and Practice teaching tasks that emphasize both students' accomplishments. The completion of academic teaching tasks is a process in which students master the knowledge and skills and practice and apply the learning process. Under the drive of the teaching method of teachers, students will gradually grasp the improvement of practical applied knowledge and skills and the development of professional competence.

There is a famous saying that is not a famous saying: Teachers teach so that they do not teach. Teaching in many educational concepts clearly points out that teachers' teaching is to enable students to gain development, and the biggest factor in students' development is their own initiative. Self-directed learning is the core method for students to achieve true improvement. Teachers' teaching is only a guide for students. Through the guidance of teachers, students gradually acquire some knowledge of learning methods and ideas from teachers' teaching. Utilize and guide these teachers to carry out knowledge discovery and knowledge learning, and ultimately gain real capacity improvement. The improvement of students' self-learning ability can also be said to be the improvement of students' self-development ability, which is the key to the improvement of students' professional ability.

\section{English Major Teaching Model Based on the "Work Process" Concept}

The most basic basis for teaching English is teaching content. In English teaching, the carrier of teaching content is teaching material. Therefore, the importance of teaching materials is self-evident. The construction of teaching materials is indispensable for the construction of the English subject 
curriculum system. The teaching reform of English majors must be started from the roots, that is, textbooks and subject curriculum systems. If teachers want to truly realize the guiding role of "work process" in English major teaching, they must dare to break the original pattern, reform the original teaching materials and subject curriculum system, adjust the structural design of the subject curriculum, and revise. The syllabus for English majors teaching, building and perfecting the new English major course system, making it compatible with the English teaching objectives under the guidance of the concept of "work process".

In order to truly achieve structural optimization and efficiency optimization through reforms, the English major teaching must understand one principle: It is not enough to have theoretical study and theoretical mastery, only knowledge and skills learned in practice. Theoretical content is applied practically and enables the mastery of knowledge and skills to be redeveloped in practice. This is the combination of practice and theory. The combination of learning and practical application of knowledge and skills will enable English major teaching to truly maximize efficiency. In the English professional teaching model based on the concept of "work process", the English professional teaching is to firmly integrate the "work process" concept, so that the English professional teaching gradually realizes the essential meaning of its teaching, namely "cultivating people ". What needs to be done in this combination of theory and practice is to develop and use some teaching resources as much as possible to promote the professional ability of English majors. For example, teachers can provide students with a large number of educational resources through some teaching and training courses and online courses, so that students can gain some knowledge about the improvement of their professional ability.

Traditional teaching evaluation methods have already been phased out. The new teaching methods should absorb lessons learned from traditional teaching evaluation methods and improve the contents, methods, and processes of evaluation. In teaching evaluation, emphasis is placed on improving students' abilities. The combination of process evaluation and result evaluation is the main method of evaluation. Specifically, teachers can adopt some of the more innovative evaluation methods, such as student anonymous evaluation of teachers, that is, more encouragement evaluation for students, teacher evaluation more concerned about the student's growth process and so on. The emphasis on evaluation methods enables students to obtain real development from the teaching evaluation of teachers.

\section{Acknowledgements}

The 2016 annual project of Hubei Educational Science Planning - A Study on the construction strategy of "double teachers and double energy" teachers in the context of the transition and development of Applied Colleges and universities (number: 2016GB159)

\section{References}

[1] Cui Yuanling. Exploration and Practice of Higher Vocational English Teaching Based on Work Process Guidance [J] Science, Education and Literature, 2009 (12)

[2] Yan Zhonghua. Vocational Education Curriculum Development and Implementation [M] Beijing: Tsinghua University Press, 2009

[3] Chen Bin. Construction of practical teaching system of business English major in vocational college based on work process[J] Journal of Chongqing Vocational College of Electronics Engineering, 2010, (5)

[4] Yao Jianhua, Zhu Xiaoqin. Problems and countermeasures in the practical teaching of business English majors in higher vocational colleges [J] Fujian Higher Education Research, 2008, (2)

[5] Jiang Dayuan. Thinking on basic issues of vocational education (II)[J] Vocational and Technical Education: Science and Education, 2006, (4)

[6] Cui Xiumin. On the Construction of Practical English Teaching System for Business English Majors in Higher Vocational Education [J]. Chinese Adult Education, 2007, (14). 